\title{
Lav risiko for kreft etter strålebehandling
}

\section{Strålebehandling av prostatakreft gir $\varnothing k t$ risiko for visse typer kreft senere i livet. Men den absolutte risikoen er lav.}

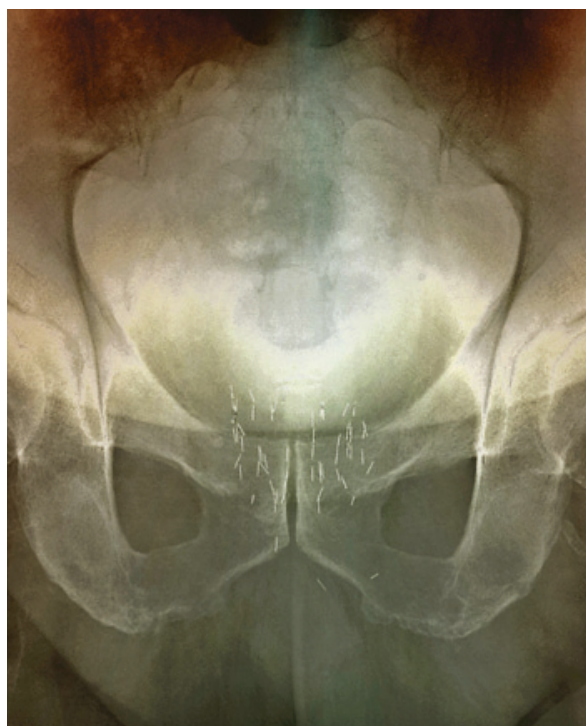

Illustrasjonsfoto: Science Photo Library
Prostatakreft er den vanligste kreftformen hos menn, og mange pasienter får strålebehandling. Hva er risikoen for nyoppstått kreft som følge av behandlingen, såkalt sekundærkreft? I en ny metaanalyse, publisert i tidsskriftet $B M J$, ble det inkludert 21 kohort- og pasientkontroll-studier der adenokarsinom i prostata ble behandlet med forskjellige former for stråleterapi, inkludert ekstern bestråling og brakyterapi (1). I kontrollgruppene ble det gitt kirurgisk behandling, andre behandlingsformer eller ingen behandling.

Strålebehandling ga økt risiko for blærekreft (justert hasardrisiko 1,67), kolorektalkreft (HR 1,79) og rectumkreft (HR 1,79), sammenliknet med dem som ikke ble strålebehandlet. Risikoen for blodkreft og lungekreft var ikke økt. Subanalyser viste at ekstern strålebehandling ga økt risiko for sekundærkreft, mens brakyterapi, gitt som eneste form av strålebehandling, ikke gjorde det. Forfatterne understreker at den absolutt risikoen for sekundærkreft likevel er lav.

- Norske stråleterapeuter har i mange år vært klar over assosiasjonen mellom strålebehandling av prostatakreft og faren for ny kreft i urinblære og rectum, sier Sophie Fosså, spesialist i onkologi og professor eme- rita ved Universitetet i Oslo. - Denne risikoen har vært ansett som lav, men slik risikovurdering er spesielt viktig hos yngre pasienter med forventet videre levetid på over ti år. Artikkelen inneholder derfor bare begrenset ny kunnskap, understreker hun.

- Studien bekrefter at risikoen for sekundærkreft er lav, sier hun. - Sammenlignet med utvikling av kreft i rectum og blære hos 100 pasienter uten strålebehandling er risikoen økt med to menn hvis de har fått strålebehandling.

Studiens uunngåelige begrensning er at den omtalte eksterne strålebehandlingen ble gitt med utdaterte teknikker, og at man i artikkelen ikke engang diskuterer størrelsen på strålefeltet som risikofaktor. Med dagens teknikker unngår man i mye større grad enn tidligere å bestråle blære eller rectum, sier hun.

\section{Ketil Slagstad \\ Tidsskriftet}

\section{Litteratur}

1. Wallis CJ, Mahar AL, Choo R et al. Second malignancies after radiotherapy for prostate cancer: systematic review and meta-analysis. BMJ 2016. 352: i851.

\section{Ikke langvarig antibiotikabehandling ved sykdom tilskrevet borreliose}

\section{Borreliose skal behandles med antibiotika, men det er ikke grunnlag for å fortsette med langvarig antibiotikabehandling hvis symptomene vedvarer.}

I en nederlandsk studie deltok 280 pasienter med vedvarende plager etter en gjennomgått borreliainfeksjon. Pasientene ble randomisert til 12 ukers behandling med enten doksysyklin, klaritromycin pluss hydroksyklorokin eller placebo. Etter de 12 ukene var det ingen signifikant forskjell i helserelatert livskvalitet mellom de tre gruppene. I alle gruppene ble pasientene bedre i løpet av perioden, men bedringen var altså ikke større med antibiotikabehandling enn med placebo.

- Endelig har vi en europeisk, godt designet studie som bekrefter at langvarig antibiotikabehandling ikke hjelper ved plager relatert til borreliose, sier Randi Eikeland, som er nevrolog og leder for Nasjonal kompetansetjeneste for flåttbårne sykdommer. - Dette har vært vist $i$ amerikanske studier flere ganger tidligere, men studiene har vært kritisert for valg av metode. I tillegg har man vært usikker på overføringsverdien til Europa, ettersom Borrelia i Amerika stort sett er en annen type enn dem man ser her og dermed kan gi et annet klinisk bilde, sier hun.

- Det er ingen tvil om at resultatene av denne studien er overførbare til Norge, blant annet fordi forekomsten av borreliaarter er ganske lik. Dette underbygger dagens norske retningslinjer, der det ikke anbefales langvarig eller kombinert antibiotikabehandling ved vedvarende plager etter nevroborreliose, sier Eikeland.

\section{Martine Rostadmo}

Tidsskriftet

\section{Litteratur}

1. Berende A, ter Hofstede HJM, Vos FJ et al. Randomized trial of longer-term therapy for symptoms attributed to Lyme disease. N Engl J Med 2016: 374: $1209-20$

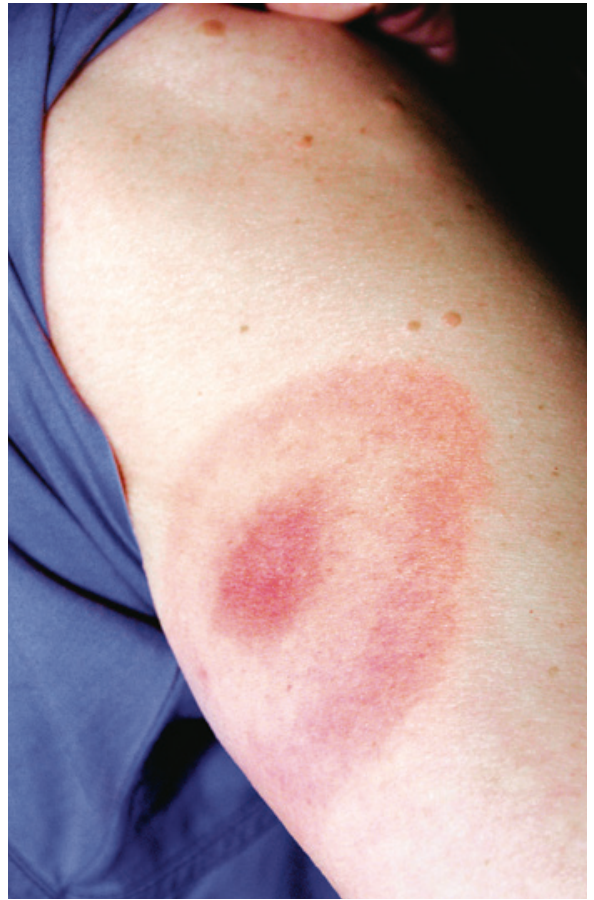

Illustrasjonsfoto: Science Photo Library 